\title{
The role of motivation and metacognition on the development of cognitive and affective responses in physical education les- sons: A self-determination approach
}

\author{
O papel da motivação e metacognição no desenvolvimento das respostas \\ afetiva e cognitiva em aulas de educação física: uma abordagem centrada \\ na teoria da autodeterminação
}

Yannis Karagiannidis ${ }^{1}$, Vassilis Barkoukis ${ }^{2 *}$, Vassilis Gourgoulis ${ }^{1}$, George Kosta ${ }^{1}$, Panagiotis Antoniou ${ }^{1}$

ARTIGO ORIGINAL | ORIGINALARTICLE

\begin{abstract}
The study investigated the role of motivation and metacognition in the formation of cognitive and affective outcomes from participation in physical education lessons within the framework of self-determination theory. A sample of 630 adolescents $(M$ age $=14.06, \mathrm{SD}=.29)$ participated in the study. Participants completed questionnaires including measures of perceived autonomy support in $\mathrm{PE}$, autonomous motivation in PE, metacognitive processes in PE, enjoyment, boredom in PE and intention for leisuretime physical activity. Multiple linear regression analyses revealed that perceptions of autonomy supportive motivational climate significantly predicted enjoyment, boredom and intentions towards leisuretime physical activity. In addition autonomous motivation and metacognition significantly predicted enjoyment, boredom and intentions, whereas controlling motivation was a significant predictor of boredom. Multiple mediation modeling indicated that perceptions of autonomy supporting climate on these responses was mediated mainly by autonomous motivation and metacognition. The findings of the present study provide valuable information on the mediating role of autonomous motivation and metacognition on the effects of autonomy supportive motivational climate on students' cognitive and affective responses during physical education lessons.
\end{abstract}

Key words: Motivation, metacognition, cognitive, affective, physical education

ABSTRACT

O estudo investigou o papel da motivação e metacognição na formação de resultados cognitivos e afetivos da participação nas aulas de educação física no âmbito da teoria da autodeterminação. Uma amostra de 630 adolescentes $(\mathrm{M}=14.06, \mathrm{SD}=0.29)$ participaram do estudo. Os participantes preencheram questionários, incluindo medidas de apoio autonomia percebida em PE, motivação autônoma em PE, processos metacognitivos em PE, prazer, o tédio em PE e intenção para a atividade física de lazer. As análises de regressão linear múltipla revelou que a perceção de autonomia clima motivacional favorável predisseram significativamente prazer, o tédio e as intenções para com a atividade física no tempo livre. Além motivação autônoma e metacognição predisseram significativamente prazer, o tédio e intenções, enquanto controlando motivação foi um preditor significativo de tédio. Modelagem múltipla mediação indicou que das perceções de autonomia apoiar climáticas sobre essas respostas foi mediado principalmente pela motivação autônoma e metacognição. Os resultados do presente estudo fornecem informações valiosas sobre o papel mediador de motivação autônoma e metacognição sobre os efeitos da autonomia clima motivacional favorável sobre as respostas cognitivas e afetivas dos alunos durante as aulas de educação física.

Palavras-chave: Motivação, metacognição, cognitivo, afetivo, educação física

Manuscript received March 26 $6^{\text {th }}, 2014$; Accepted June $6^{\text {th }}, 2014$

${ }^{1}$ Department of Physical Education and Sport Science, Democritus University of Thrace, Greece

${ }^{2}$ Department of Physical Education and Sport Science, Aristotle University of Thessaloniki, Greece

* Corresponding author. Aristotle University of Thessaloniki, 57001, Thessaloniki, Greece; E-mail: bark@phed.auth.gr 


\section{INTRODUCTION}

Developing students' metacognitive abilities is a focal aim of the educational process (Thomas \& Mee, 2005). There is growing evidence suggesting that increased metacognitive abilities are associated with better learning performance and contribute to adaptive learning processes (Veenman, Wilhelm, \& Beishuizen, 2004). The present study was designed to investigate the effect of teacher-initiated motivational climate on the formation of adaptive cognitive and affective responses during physical education lessons, and the potential mediating role of motivational regulations and metacognition.

Metacognition can be defined as the knowledge about and regulation of one's cognitive activities in learning processes and can be operationalized into two key functions namely monitoring (metacognitive knowledge and metacognitive experience) and regulatory (goals and activation of strategies) functions (Efklides, 2001; Flavell, 1979). Metacognition is usually utilized synonymously with self-regulation and self-regulating learning (Kaplan, 2008), and appears to be as one of the profound predictors of learning and a key construct in students' development and their academic success (Winne \& Nesbit, 2010). Metacognitive learners are able to recognize when they are effectively learning and employ the use of additional strategies to control or monitor their motivation (Alexander, 2008). For instance, proficient performers in the psychomotor domain, compared to their average peers, are more accurate in framing a problem and predicting occurrences, utilize more strategies to address difficulties, choose and use strategies more accurately, efficiently, spontaneously, and continuously for planning, monitoring and evaluating their performance (Martini \& Shore, 2008; Nietfeld, 2003).

In physical education settings the investigation of metacognition is rather limited and has largely focused on the association of metacognitive strategies with the dispositional and situational aspects of goal orientations. For instance,
Kolovelonis, Goudas \& Dermitzaki (2011) indicated that self-recording of self-regulating learning had a positive effect on motor skill performance in physical education settings. In terms of the psychological correlates of metacognition, Solmon and Boone (1993), Solmon and Lee (1997), Ommundsen (2003, 2006), and Theodosiou, Mantis and Papaioannou (2008) indicated that task involvement and task orientation were positively related with the use of metacognitive strategies (i.e., effort regulation, help-seeking, planning, monitoring and regulating cognition). On the other hand, ego involvement and ego orientation were negatively related to the use of such strategies.

\section{Self-determination theory}

Self-determination theory (SDT; Deci \& Ryan, 2000, 2011; Ryan \& Deci, 2000a, 2000b) acknowledges that human behavior is guided by different motivational regulations that vary in their levels of self-determination (Deci \& Ryan, 2000). There are three types of motivation, namely intrinsic motivation, extrinsic motivation and amotivation to account for the different reasons why individuals engage in activities (Deci \& Ryan, 2011). Intrinsic motivation is the most self-determined type of motivation and is defined as the involvement in an activity for inherent satisfaction and pleasure (Ryan \& Deci, 2000a). Intrinsically motivated people are moved to act for the fun, challenge and excitement of doing so (Niemiec \& Ryan, 2009). Extrinsic motivation reflects the engagement in a behavior or activity for reasons separate for the activity itself (Ryan, Williams, Patrick, \& Deci, 2009). In SDT there have been identified four regulations varying in self-determination. The least self-determined type of extrinsic motivation is external regulation, whereby behaviors are enacted to satisfy an external demand or to obtain an externally imposed reward contingency (Niemiec \& Ryan, 2009; Ryan \& Deci, 2000a). A student who takes part in physical education (PE) lessons only because he is afraid of being punished by the teacher would be externally regulated (Taylor, Ntoumanis, Standage, 
\& Spray, 2010). The second type of extrinsic motivation is introjected regulation which represents motivation that is internalized but not still part of the integrated self (Wininger \& DeSena, 2012). Behaviors are enacted with the feeling of pressure to avoid self-disapproval (shame or guilt), to attain ego-enhancements or to experience pride (Ryan \& Deci, 2000a; Ryan et al., 2009). A student who takes part in an after school physical activity program because that is what 'good students' do, is an example of someone motivated by introjected regulation (Standage, Duda, \& Ntoumanis, 2005). Moving toward greater self-determination, the third type of extrinsic motivation is identified regulation. People engaging in behaviors, which considered personally valuable or important, are motivated by identified regulation (Ryan \& Deci, 2000a, 2006; Ryan et al., 2009). In identified regulation individuals are expressing more choice concerning their participation as compared to introjected and external regulation. However, the behavior remains extrinsically motivated as the underlying motive is still instrumental (i.e., the usefulness of the activity rather than the activity's inherent interest) (Deci \& Ryan, 2000; Standage et al., 2005). An adolescent who takes part in a leisure-time physical activity program because she/he values the health benefits of physical activity, is an example of an identified regulated person. The fourth type of extrinsic motivation, with the highest degree of self-determination, is integrated regulation. Integration occurs when identified regulations have been fully assimilated into the self and are congruent and well synthesized with one's values, goals and needs (Ryan \& Deci, 2000a; Ryan et al., 2009). For example, a person with a high degree of integrated regulation would exercise because exercising is an important aspect of the individual's self-concept (Wininger \& DeSena, 2012). Previous research has reported that integrated regulation is more often encountered among adults rather than among children and adolescents, as younger populations are too young to achieve a sense of integration within their self (Deci \&
Ryan, 2000; Vallerand, 1997, 2001). Thus, this construct has not typically been assessed in this population. Finally, amotivation, the least autonomous type of motivation, is defined as the lack of intention to act and reflects the absence of both intrinsic and extrinsic motivation (Deci \& Ryan, 2000). An example of amotivation is a student who is not sure why he participates in physical education and only contributes passively or not at all (Taylor et al., 2010).

Self-determination theory postulates that social agents (i.e, teachers, parents, coaches) influence the formation of motivation in a specific context (Deci \& Ryan, 2002; Vallerand, 2007). Perceptions of autonomy supportive climate (i.e., providing choices, rationales, informational feedback, encouragements and hints, and allowing students work on their pace; see Reeve \& Jang, 2006) are expected to increase autonomous motivation (i.e., intrinsic motivation and identified regulation). On the other hand, perceptions of a controlling climate (i.e., uttering solutions and commands, using deadline statements and criticizing students; see Reeve \& Jang, 2006) are thought to positively influence controlling motivation (i.e., external and introjected regulations) (Deci \& Ryan, 2002). Prior research in physical education has consistently supported the tenets of the theory and suggested that autonomy supportive climate consistently results in autonomous motivation in physical education (Barkoukis, Hagger, Lambropoulos, \& Tsorbatzoudis, 2010; Cox \& Williams, 2008; Standage et al., 2005; Standage, Duda, \& Ntoumanis, 2006). Importantly, an autonomy supportive climate is crucial in developing and maintaining adaptive motivational patterns in adolescence. Past evidence has shown a decline in adaptive motivational patterns (i.e., autonomous motivation, need satisfaction, mastery goals) and affective responses in physical education lessons during junior high school years (Barkoukis, Ntoumanis, \& ThøgersenNtoumani, 2010; Ntoumanis, Barkoukis, \& Thøgersen-Ntoumani, 2009). Fostering an au- 
tonomy supportive climate is considered an effective way to tackle this decline in adolescence (Reeve, Jang, Carrell, Jeon, \& Barch, 2004).

With respect to the outcomes of motivation, the theory proposes that autonomous motivation lead to greater levels of effective functioning and personal adjustment as compared to controlling motivation (Vallerand, 2001, 2007). According to the theory, motivational regulations can influence several cognitive, affective, and behavioral consequences. Autonomous motivation is associated with positive outcomes, such as greater persistence in the face of obstacles, better performance, more effort, concentration and a positive experience during the activity, whereas controlling motivation has a neutral or negative effect on these outcomes (Taylor et al., 2010; Vallerand, 2007). Past research in physical education supported the theory's premises (Duncan, Hall, Wilson, \& Jenny, 2010; Standage et al., 2005; Vansteenkiste, Simons, Soenens, \& Lens, 2004; Wilson \& Rodgers, 2004).

\section{Students' responses in physical education les- sons}

Enjoyment and boredom are among the most influential affective responses in physical education lessons. Enjoyment as a positive affect reflects generalized feeling states described in terms such as "enjoy", "happy", "like" and "fun" (Scanlan \& Simmons, 1992). It has been recognized as a key motivating factor for participation and sustained involvement in youth sport, physical activity (PA) and physical education (Office for the Minister of Children and Youth Affairs, 2007; Prochaska, Sallis, Slymen, \& McKenzie, 2003; Sallis, Prochaska, \& Taylor, 2000; Smith \& Saint-Pierre, 2009; Wallhead \& Buckworth, 2004; Weiss, Kimmel, \& Smith, 2001).

Enjoyment of physical education represents a direct and tangible influence on students' participation in physical education, acting, thus, as a consequence of participation, in contrast to intrinsic motivation which reflects the reason for participation. Past research in PE settings has indicated the strong link between enjoyment and intrinsic motivation (Ntoumanis, 2002). Intrinsic motivation has been consistently associated with higher enjoyment (Yli-Piipari, Wang, Jaakkola, \& Liukkonen, 2012; Yli-Piipari, Watt, Jaakkola, Liukkonen, \& Nurmi, 2009). Also, PE enjoyment mediates the relationship between autonomous motivation in PE and leisure time physical activity (Cox, Smith, \& Williams, 2008).

Boredom is an indefinable feeling that induces discomfort, resentment, guilt and, sometimes, pleasure (Belton \& Priyadharshini, 2007; van Tilburg, Igou, \& Sedikides, 2013), and is characterized by a lack of stimulation, variation, challenge, arousal, or meaning. Bored people are motivated to engage in strategies in order to reestablish a sense of meaningfulness (van Tilburg \& Igou, 2011). Boredom is one of the neglected emotions in the educational research as compared to anxiety (Pekrun, Goetz, Titz, \& Perry, 2002), but there is evidence suggesting that boredom is experienced more frequently than anxiety (Goetz, Frenzel, Pekrun, \& Hall, 2006).

Boredom in school settings may often be overlooked because it is an inconspicuous, silent and nondisruptive emotion, compared to anger and anxiety (Nett, Goetz, \& Daniels, 2010; Pekrun, Goetz, Daniels, Stupnisky, \& Perry, 2010). But it is associated to many negative attitudes and behaviors (Nett et al., 2010). Boredom in school settings is positively related to truancy (Kearney, 2008), drop-out rates (Wegner, Flisher, Chikobvu, Lombard, \& King, 2008) attention deficits and deviant behavior (Kass, Wallace, \& Vodanovich, 2003; Wasson, 1981).

Leisure-time physical activity participation is among the most important outcome goals of physical education curricula (Klein \& Hardman, 2008). The most proximal predictor to actual physical activity behaviour is intentions (Hagger, Chatzisarantis, \& Biddle, 2002). Therefore, physical education lesson should aim to develop strong intentions towards leisuretime physical activity. Past evidence under the 
scope of SDT has shown that autonomous motivation in PE can increase intentions to participate in physical activity (Barkoukis \& Hagger, 2009; Barkoukis, Ntoumanis, et al., 2010; Hagger, Chatzisarantis, Culverhouse, \& Biddle, 2003).

\section{The present study}

Prior research has suggested that metacognition may act as a mediator in the motivational climate - PE outcomes relationship. More specifically, Theodosiou and Papaioannou (2006) provided evidence that metacognition may mediate the effect of perceptions of learning climate and task orientation on the frequency of sport and exercise involvement. In addition, Barkoukis, Katsani \& Ourda (2012) reported similar findings. More specifically, approach achievement goals, perceptions of learning motivational climate and satisfaction of basic psychological needs were found to be significant and positive predictors of student's metacognition during physical education lessons. In turn, metacognition predicted positively students' enjoyment, and negatively boredom. These findings imply a mediating role of metacognition on the effect of motivational-related constructs and outcomes from participating in PE lessons. Both these studies investigated perceptions motivational climate under the scope of achievement goal theory. On the other hand, self-determination theory provides a solid theoretical background explaining the process, through which perceptions of motivational climate can influence PE outcomes (Ntoumanis, 2005; Standage, Duda, \& Ntoumanis, 2003; Standage et al., 2005). There is a lack of consistent evidence in PE incorporating metacognition in the motivational sequence described by self-determination theory in order to explain the effect of teacher initiated climate on PE outcomes. Thus, the aim of the present study was to investigate the role of metacognition on the effect of perceptions of motivational climate on the cognitive and affective responses from participation in physical education lessons. Based on past evidence under the lens of self-determination theory it was hypothesised that perceptions of autonomy supportive motivational climate would positively predict enjoyment and intentions towards leisure-time physical activity and negatively predict boredom (hypothesis 1 ). Autonomous motivation and metacognition were assumed to have a positive effect on enjoyment and leisure-time physical activity intentions and a negative effect on boredom (hypothesis 2a). Contrary, controlling climate was expected to show a negative effect on enjoyment and leisure-time physical activity intentions and a positive one on boredom (hypothesis $2 \mathrm{~b}$ ). The effect of autonomy supportive climate on PE outcomes will be mediated by autonomous and controlling motivation, and metacognition (hypothesis 3).

\section{Participants}

\section{METHOD}

The sample of the study consisted of 630 adolescents (313 girls, 314 boys, 3 did not reported their gender; $M$ age $=14.06, \mathrm{SD}=.29$ ) from two junior high schools located in Southern Greece. According to school directors the socioeconomic status of adolescents could be described as low to middle class. The majority of the participants in the study were native Greek nationals, with a small minority (4\%) being immigrants from countries of Balkans and former Soviet Union. These adolescents were second generation immigrants with Greek as their first language.

\section{Measures}

Perceived Autonomy Support in PE.

Autonomy support in PE was measured with an adapted version of the Perceived Autonomy Support Scale for Exercise Settings (PASSES; Hagger \& Chatzisarantis, 2007). Participants were asked to rate the extent that PE teachers supported their autonomy during the lesson. The scale consists of 15 items (e.g., "I feel that my PE teacher gives me choices and opportunities"). Responses were given on a 7-point Likert scale ranging from 1 (strongly disagree) to 7 
(strongly agree). The measure has been used with Greek students in the past showing satisfactory psychometric properties (Barkoukis \& Hagger, 2009). The internal consistency of the scale in the present study was high $(\alpha=.90)$.

\section{Autonomous motivation in PE.}

Autonomous motivation in PE was measured via a modified version of Perceived Locus of Causality scale (PLOC; Ryan \& Connell, 1989), which measures four motivational regulations. The common stem "I participate in PE because.." was followed by eight reasons, two for each regulation: intrinsic motivation (e.g., “...PE is fun"), identified regulation (e.g., "...it is important for me to participate in PE"), introjected regulation (e.g., “...I want my PE teacher to consider me as a good student"), and extrinsic regulation (e.g., "...I will have problems if I don't do it"). Responses were anchored on a 4point Likert scale ranging from 1 (strongly disagree) to 4 (strongly agree). The construct and discriminant validity of the PLOC measure has been supported in previous studies (Hagger et al., 2003). Barkoukis and Hagger (2009) using this scale with Greek students reported satisfactory psychometric characteristics.

\section{Metacognitive Processes in PE.}

To assess students' metacognitive activity, a modified version of the Metacognitive Processes in Physical Education Questionnaire (MPIPEQ; Theodosiou, 2004) was administered. Based on Brown's (1987) framework on metacognition, MPIPEQ concerns with two metacognitive functions: knowledge and regulation of cognition. The modified version of MPIPEQ consists of 27 items measuring seven factors: declarative knowledge (six items, e.g., “...I realize in which sports I am doing well”), procedural knowledge (three items, e.g., "...I know how to apply on my own a learning strategy that I was taught (a strategy which helps me to learn)"), conditional knowledge (three items, e.g., "...in order to learn a new exercise I use a learning strategy (e.g. ...from easy to difficult)", information management (three items: e.g., "...I am thinking whether the exercise I am learning resembles with another one I already know"), mental imagery (three items: e.g., "...before I perform an exercise I imagine myself performing it well"), self-monitoring (six items: e.g., “...while performing an exercise, I check if I perform it well”), and evaluation (three items: e.g., “...as soon as I have learned an exercise I think if I learned it through the easiest way"). The items followed the common stem "In PE lessons...", and responses were given on a 5-point Likert scale $(1=$ Neverto $5=$ Always $)$. An exploratory factor analysis performed with this study's data revealed seven factors explaining $61.08 \%$ of total variance, whereas a subsequent confirmatory factor analysis with this dataset further supported the factor structure of the scale (CFI = .90$, SRMR $=.72$, RMSEA $=.53)$. All items and subscales indicated normal distribution, and low to moderate inter-correlations. The internal consistency of the scale was adequate with Cronbach's alphas of the subscales ranging from .71 to .84 . In the present study a composite score was calculated by averaging the subscales in order to facilitate the analyses. The alpha of the total score was .89 .

\section{Enjoyment in $P E$.}

Enjoyment in PE was measured using the "Interest-Enjoyment" subscale of the Intrinsic Motivation Inventory (McAuley, Duncan, \& Tammen, 1989). Following the common stem "In PE lessons..." the measure includes 4 items (e.g., "I am very happy"). Responses were given on a 7 -point Likert scale $(1=$ totally disagree to 7 = totally agree). Barkoukis, Tzorbatzoudis, Grouios, and Gabrii-lides (2003) adapted the scale in Greek and provided evidence on its psychometric properties. The Cronbach $\alpha$ of the scale in the present study was .90 .

\section{Boredom in PE.}

Boredom in PE was measured via an adapted for PE version of the Boredom Scale (Duda \& Nicholls, 1992). The common stem "In PE lessons..." was followed by 3 items (e.g., "..I am usually bored"). Responses were given on a 7 - 
point Likert scale $(1=$ totally disagree to $7=$ totally agree). Barkoukis, Ntoumanis, and Thøgersen-Ntoumani (2010) provided evidence on the psychometric characteristics of the scale with adolescents. The internal consistency coefficient of the scale in the present study was adequate $(\alpha=.76)$.

\section{Intention for Leisure-Time Physical Activity.}

Intention was measured based on Ajzen's (2011) recommendations. Four items were used to measure intentions (e.g., "During my leisure time I intend to do active sports and/or vigorous physical activities, for at least 30 minutes, 3 times per week, in the next 3 weeks..."). Participants' responses were given on a 7-point Likert scale anchored from 1 (not likely at all) to 7 (very likely). The Cronbach $\alpha$ of the scale was .77.

\section{Procedure}

A written permission from the Ministry of Education, Lifelong Learning and Religious Affairs was granted to conduct the study. A stratified sampling approach was used to randomly select 2 school units. School principals of these units were informed on the aim and procedure of the study and consented to participate. Students' informed consent was also obtained. A pre-print form was provided to students for their parents to sign and return to the class teacher if they did not want their child to participate in the study. No forms where returned in any case. Students were informed that participation in the study was voluntary, and they could withdraw at any time of data collection. All children accepted to complete the questionnaire. Data collection was supervised by the first author. Both oral and written instructions were given to students. Also, students were reassured about the anonymity and confidentiality of their responses. The completion of the questionnaire lasted approximately 20 minutes.

\section{Preliminary analyses}

\section{RESULTS}

Means, standard deviations and normality statistics are presented in Table 1. The analysis of correlation indicated low to moderate relations among the study's variables. With the exception of boredom that was negatively related to all other variables, positive correlations emerged (Table 1).

Table 1

Descriptive Statistics and Analysis of Correlation

\begin{tabular}{lcccccc}
\hline & $\mathbf{2}$ & $\mathbf{3}$ & $\mathbf{4}$ & $\mathbf{5}$ & $\mathbf{6}$ & $\mathbf{7}$ \\
\hline 1. Auton. Support & $.37^{* *}$ & $.25^{* *}$ & $.29^{* *}$ & $.13^{* *}$ & $.47^{* *}$ & $-.29^{* *}$ \\
2. Auton. Motiv. PE & & $.35^{* *}$ & $.27^{* *}$ & $.16^{* *}$ & $.57^{* *}$ & $-.43^{* *}$ \\
3. Contr. Motiv. PE & & & $.21^{* *}$ & .03 & $.20^{* *}$ & $-.08^{*}$ \\
4. Metacognition & & & & $.32^{* *}$ & $.30^{* *}$ & $-.18^{* *}$ \\
5. Intention & & & & $.27^{* *}$ & $-.19^{* *}$ \\
6. Enjoyment & & & & & $-.51^{* *}$ \\
7. Boredom & & & & & \\
Mean & 3.4 & 2.77 & 3.55 & 4.77 & 5.53 & 2.51 \\
Std. Deviation & .64 & .73 & .6 & 1.27 & 1.4 & 1.51 \\
Skewness & -1.32 & -.33 & -.38 & -.47 & -.87 & .97 \\
Kurtosis & 1.77 & -.44 & -.29 & -.11 & .01 & .22 \\
\hline
\end{tabular}

Note: ${ }^{*} \mathrm{p}<.05,{ }^{* *} \mathrm{p}<.01$ 


\section{Predictors of cognitive and affective re- sponses}

Multiple linear regression analyses were used to assess the predictive effects of autonomy-supportive climate and motivational regulations and metacognition on enjoyment and boredom in physical education, and intention towards leisure-time physical activity. The analysis was completed at three steps to enable the assessment of the unique effects of autonomysupportive climate (step 1), autonomous and controlling motivation (step 2), and metacognition (step 3$)^{1}$. With respect to intentions, a significant overall model emerged ( $F=15.77, p<$ $.001)$ predicting $10.1 \%\left(\operatorname{Adj} R^{2}\right)$ of the variance in intentions. At step 1, the effect of autonomysupportive climate was statistically significant $(\beta=.13, p<.01)$. At step 2 , the addition of autonomous and controlling motivation improved the predicted variance by $1.5 \%$, and the effect of autonomy-supportive climate was reduced and was marginally significant $(\beta=.09$, $p=.049)$. Autonomous motivation emerged as the only significant predictor at this step $(\beta=$ $.13, p<.01)$. The addition of metacognition at step 3 further improved the predictive ability of the model $\left(R^{2}\right.$ change $\left.=7.4 \%\right)$. Metacognition was a significant predictor of leisure-time physical activity intentions $(\beta=.29, p<.001)$, and autonomous motivation remained, albeit marginally, significant. Autonomy-supportive climate turned non-significant implying a mediation effect (Table 2).

Table 2

Predictors of Physical Education Responses

\begin{tabular}{|c|c|c|c|c|c|}
\hline PE outcome & Step & Predictor & $\beta$ & $\mathrm{R}^{2}$ change & $\mathbf{F}$ \\
\hline \multirow[t]{8}{*}{ Intentions } & Step 1 & Autonomy support & $.13^{* *}$ & 1.8 & $9.65^{* *}$ \\
\hline & Step 2 & Autonomy support & $.09 *$ & 1.5 & $5.98^{* *}$ \\
\hline & & Autonomous motivation & $.13^{*}$ & & \\
\hline & & Controlling motivation & -.03 & & \\
\hline & Step 3 & Autonomy support & .02 & 7.4 & $15.77^{* *}$ \\
\hline & & Autonomous motivation & $.09^{*}$ & & \\
\hline & & Controlling motivation & -.06 & & \\
\hline & & Metacognition & $.29 * *$ & & \\
\hline \multirow[t]{8}{*}{ Enjoyment } & Step 1 & Autonomy support & $.47^{* *}$ & 22.2 & $150.43^{* *}$ \\
\hline & Step 2 & Autonomy support & $.30 * *$ & 18.3 & $119.13^{* *}$ \\
\hline & & Autonomous motivation & $.47^{* *}$ & & \\
\hline & & Controlling motivation & -.04 & & \\
\hline & Step 3 & Autonomy support & $.28^{* *}$ & 1.0 & $92.94^{* *}$ \\
\hline & & Autonomous motivation & $.45^{* *}$ & & \\
\hline & & Controlling motivation & $-.05^{*}$ & & \\
\hline & & Metacognition & $.10^{*}$ & & \\
\hline \multirow[t]{8}{*}{ Boredom } & Step 1 & Autonomy support & $-.29 * *$ & 8.5 & $48.90^{* *}$ \\
\hline & Step 2 & Autonomy support & $-.16^{* *}$ & 13.4 & $48.92^{* *}$ \\
\hline & & Autonomous motivation & $-.41^{* *}$ & & \\
\hline & & Controlling motivation & $.10^{*}$ & & \\
\hline & Step 3 & Autonomy support & $-.15^{* *}$ & 0.3 & $37.23^{* *}$ \\
\hline & & Autonomous motivation & $.40^{* *}$ & & \\
\hline & & Controlling motivation & $.10^{*}$ & & \\
\hline & & Metacognition & -.05 & & \\
\hline
\end{tabular}

Note: ${ }^{*} \mathrm{p}<.05,{ }^{* *} \mathrm{p}<.001$

\footnotetext{
${ }^{1}$ Past research demonstrated that motivational-related variables influence metacognition. Our assumption was that the formation of motivation will shape metacognition, and, thus, we entered metacognition in the third step of the analysis. Due to lack of thorough evidence in support of this assumption we also run a regression analysis entering metacognition at the second step alongside to motivation. The results of both analyses were identical, and we preferred to retain in the text the three step model which is more consistent with past evidence.
} 
With respect to enjoyment, the results of the hierarchical regression analysis revealed a significant overall model $(F=92.94, p<.001)$ predicting $41.1 \%\left(\operatorname{Adj} R^{2}\right)$ of the variance in enjoyment. Autonomy-supportive climate entered at step 1 significantly predicted enjoyment $(\beta=$ $.47, p<.001)$. The addition of autonomous and controlling motivation at step 2 improved the predictive ability of the model by $18.3 \%$. At this step autonomous motivation emerged as a significant predictor of enjoyment $(\beta=.47, p<$ $.001)$, but not controlling motivation. The effect of autonomy-supportive climate at this step remained significant. At step 3 metacognition significantly predicted enjoyment $(\beta=.10, p<$ .01 ), and autonomous motivation remained significant predictor of enjoyment. The effect of autonomy-supportive climate were suppressed but remained significant implying a partial mediation effect (Table 2).

Regarding boredom, the results of the analysis indicated a significant overall model $(F=$ 37.23, $p<.001)$ predicting $21.5 \%\left(\operatorname{Adj} R^{2}\right)$ of the variance. At step 1, autonomy-supportive climate revealed a unique effect on boredom $(\beta$ $=-.29, p<.001)$. At step 2 , the predicted variance was improved ( $R^{2}$ change $\left.=.13 \%\right)$ and both autonomous and controlling motivation was found to have a significant effect on bore$\operatorname{dom}(\beta=-.41,<.001$ and $\beta=.10, p<.05$ respectively). The effect of autonomy supportive climate were suppressed but remained significant at this step implying a partial mediation effect. The addition of metacognition at step 3 didn't improve the predictive ability of the model (Table 2).

\section{Indirect effects of motivational climate on physical education responses}

Multiple mediation modeling was used to investigate whether physical education motivation and metacognition mediate the effect of autonomy-supportive climate on physical education outcomes. The Preacher and Hayes (2008) approach was employed using bootstrapping (1000 resamples) and confidence intervals set at $95 \%$. The multiple mediation models tested were based on the findings from the regression analyses. With respect to intentions, the regression analysis indicated that autonomous motivation and metacognition may have a mediation effect. The results of the multiple mediation analysis indicated that autonomous motivation and metacognition fully mediated the direct effect of autonomy supportive climate on leisuretime physical activity intentions $\left(\beta_{\mathrm{c}}=.143, p<\right.$ $.01, \beta_{c^{\prime}}=.022, p>.05 ; z_{\text {autonomous }}=1.63, p>$ .05 and $\left.z_{\text {metacognition }}=4.82, p<.001\right)$. Metacognition was the only significant mediator in this relation. With regards to enjoyment, only autonomous motivation was found to have a possible mediating effect, and thus included in the multiple mediation analysis. The results of the analysis indicated that autonomous motivation partially mediated the effect of autonomy supportive climate on enjoyment $\left(\beta_{c}=.561, p<\right.$ $.001, \beta_{c^{\prime}}=.358, p<.001 ; z_{\text {autonomous }}=7.43, p<$ $.001)$. Finally, the regression analysis indicated that autonomous and controlling motivation and metacognition may mediate the effect of autonomy supportive climate on boredom. The results of the multiple mediation analysis indicated that these variables only partially mediated the direct effect of autonomy supportive climate on boredom $\left(\beta_{\mathrm{c}}=-.371, p<.001, \beta_{\mathrm{c}^{\prime}}=\right.$ -.194, $p<.001 ; z_{\text {autonomous }}=-6.50, p>.001, z$ controlling $=2.37, p<.05$ and $z_{\text {metacognition }}=-1.36$, $p>.05)$. Further analysis indicated that autonomous motivation had a stronger mediating effect as compared to controlling motivation.

\section{DISCUSSION}

The present study set out to examine the role of motivation and metacognition in the formation of cognitive and affective outcomes from participation in physical education lessons within the framework of self-determination theory. The findings of the study indicated that perceptions of autonomy supportive motivational climate significantly predicted enjoyment, boredom and intentions towards leisure-time physical activity. In addition autonomous motivation and metacognition significantly predicted en- 
joyment, boredom and intentions, whereas controlling motivation was a significant predictor of boredom. The effect of perceptions of autonomy supporting climate on these responses was mediated mainly by autonomous motivation and metacognition.

More specifically, the findings supported the first hypothesis on the direct effect of perceptions of motivational climate on the cognitive and affective responses tested. Perceptions of autonomy supportive climate positively predicted enjoyment and intentions and negatively boredom. These findings are in line with theoretical predictions (Deci \& Ryan, 2002; Vallerand, 2007) and past evidence in physical education (Barkoukis, Ntoumanis, et al., 2010; Cox \& Williams, 2008; Standage et al., 2005, 2006). Autonomy supportive climate seems to consistently have a positive influence on students' responses during physical education lessons. This is of crucial importance for physical educators, who can establish positive experiences in their lessons by employing autonomy supportive strategies. Increasing the time of listening, asking students what they want, and communicating perspective-taking statements are examples of strategies that may enhance enjoyment and diminish boredom during the lesson. Also, providing informational feedback, encouragements and hints may increase students' perceptions of competence, which, in turn, may form higher intentions towards leisure-time physical activities (Reeve \& Jang, 2006).

Consistent with self-determination theory and the second hypothesis autonomous motivation exerted a positive effect on enjoyment and leisure-time physical activity intentions and a negative effect on boredom. These findings indicate the positive influence autonomous motivation has on students' responses during physical education lessons. This finding is consistent in the literature and suggests that physical education teachers should promote students' autonomous motivation in order to booster positive experiences in the lesson such as high enjoyment, and diminish negative experiences such as boredom. Importantly, autonomous motivation influenced intentions towards leisure-time physical activity. Intentions are thought to be the most influential predictor of actual behaviour (Ajzen, 1985; Webb \& Sheeran, 2006). This is also true for physical activity participation (Hagger et al., 2002). Hence, these findings imply that the development of autonomous motivation in school physical education may influence students' out of school physical activity behaviour.

The analyses revealed interesting findings regarding the effect of metacognition on students' responses. Metacognition was a positive predictor of leisure-time physical activity intentions and enjoyment, but had no effect on boredom. Metacognition involves active participation in the lesson through planning and monitoring the learning process. Thus, it is probable that this active involvement results in higher enjoyment during the lesson as compared to a more mechanistic participation characterized by a simple reproduction of the motor activities demonstrated by the teacher. In addition, planning learning strategies and monitoring achievement might have influenced the formation of leisure-time physical activity intentions.

In line with the findings on the effect of autonomous motivation on leisure-time physical activity intentions, these findings denote an important psychological mechanism. The transcontextual model of motivation (Hagger et al., 2003) has provided a description of the process through which school physical education influences leisure-time physical activity. Briefly, the establishment of autonomous motivation in physical education through autonomy-supportive strategies will increase autonomous motivation in leisure-time physical activity. This, in turn, will positively influence the decision making process (i.e., attitudes, norms, perceived behavioural control and intentions) and, at the end, will increase actual behaviour.

The findings of the present study indicate that metacognition may also facilitate a positive decision towards physical activity behaviours. Metacognitive learners are able to regulate their 
motivation (Alexander, 2008), and probably their relevant motivational schemata. Thus, metacognition may facilitate the transference of motivation from one context (i.e., physical education) to another similar one (i.e., physical activity) proposed by the trans-contextual model. If this is the case, the present findings imply an important addition to the trans-contextual model enhancing our understanding of the psychological mechanism underlying the effect of school physical education on out of school physical activity.

The results pertaining to controlling motivation partially supported the second hypothesis. Controlling motivation positively predicted boredom but had no effect on enjoyment and leisure-time physical activity intentions. These findings support theoretical prediction (Deci \& Ryan, 2002) suggesting that controlling motivation has a negative or neutral effect on the students' responses. With respect to boredom, these findings indicate that strategies involving uttering and demonstrating the solutions and the answers to the tasks at hand, uttering commands and making ought to statements, and increased time of teacher talking and monopolizing learning material (see Reeve \& Jang, 2006) creates an environment where students do not have fun, lose attention and get bored. Similarly, practices including criticizing students and using deadlines leads to a lesson that doesn't promote positive experiences towards the lesson and physical activity in general. Clearly, physical education teachers should avoid using such strategies and try to promote an autonomy-supportive environment in order to maximise students' positive experiences during the lesson.

Lastly, we assumed that the effect of autonomy supportive climate on PE outcomes will be mediated by autonomous and controlling motivation, and metacognition. With respect to leisure-time physical activity intentions, the findings of the multiple mediation analyses indicated that metacognition fully mediated the effect of autonomy support. These findings corroborate our past findings and indicate that metacognition may play an important role in describing and explaining the mechanism through which teacher-initiated climate influences out of school physical activity. Metacognitive learners seem to perceive autonomy-supportive strategies as more effective and employ them to regulate motivation (Alexander, 2008). We assume that this may be true for similar contexts, for instance, regulation of motivation in physical education and leisure-time physical activity. However, this is just an assumption and future research should investigate this premise.

With respect to affective responses, metacognition did not have a significant mediating effect. This might indicate that the metacognitive use of teacher's autonomy-supportive strategies was not translated into positive affective experiences in physical education. Clearly, more research is needed on the association between metacognition and affect in physical education. On the other hand, autonomous and controlling motivation partially mediated the effect of autonomy supportive climate. These findings corroborate past evidence indicating that motivation acts as a more proximal predictor of affective responses during physical education lesson (Ntoumanis, 2001, 2005).

\section{CONCLUSION}

The findings of the study indicated that perceptions of autonomy supportive motivational climate predicted both directly and indirectly, through autonomous motivation and metacognition, students' cognitive and affective responses during physical education lessons. In addition, the present study indicated that metacognition should be studied jointly with motivation to further understand how teacher-initiated motivational climate can influence students' participation in physical education lessons and leisure-time physical activity.

However, the study is not free of limitations. One limitation pertains to the correlational nature of the study which doesn't allow for causal inferences to be made. Future research should examine the effect of training programs involving teaching strategies on students' responses, 
and the mediating role of metacognition. Currently, there is a growing interest in testing the effect of specific motivational strategies on students' responses in physical education but so far the role of metacognition has not been studied thoroughly. In addition, longitudinal designs should be also employed in future studies to test for the developmental trajectories of learning environment, motivation, metacognition and motivational-related consequences, and their possible interplay. Secondly, the study was relied on students' self- reports. Future studies should employ objective measures of students' responses that more accurately describe their behaviour (i.e. academic learning time). In addition, metacognition reflects a personal orientation. Having this in mind, one could assume that metacognition influences perceptions of learning environment which, in turn, establish adaptive cognitive and affective responses in physical education lessons. Clearly, future studies should take into account this perspective when investigating the development and role of metacognition in physical education.

Despite these limitations, the present study contributes significantly to the literature by providing evidence on the role of metacognition in the development of students' responses. Metacognition has been proliferated as a key construct in students' development and as an important determinant of academic achievement. Evidence in physical education is scarce, so far, and the present study provides important information on the role of metacognition in fostering positive experiences from physical education lessons.

Acknowledgments:

Nothing to declare.

Conflict of interest:

Nothing to declare.

\section{Funding:}

Nothing to declare.

\section{REFERÊNCIAS}

Ajzen, I. (1985). From intentions to actions: A theory of planned behavior. Em J. Kuhl \& J. Beckmann (Eds.), Action Control, from Cognition to Behavior (pp. 11-39). Heidelberg, Germany: Springer-Verlag.

Ajzen, I. (2011). Constructing a theory of planned behavior questionnaire. Obtido de www.people.umass.edu/aizen/pdf/tpb.measurement.pdf

Alexander, P. A. (2008). Why This and Why Now? Introduction to the Special Issue on Metacognition, Self-Regulation, and Self-Regulated Learning. Educational Psychology Review, 20(4), 369-372. http://doi.org/10.1007/s10648-0089089-0

Barkoukis, V., \& Hagger, M. S. (2009). A Test of the Trans-Contextual Model of Motivation in Greek High School Pupils. Journal of Sport Behavior, 32(2), 152.

Barkoukis, V., Hagger, M. S., Lambropoulos, G., \& Tsorbatzoudis, H. (2010). Extending the transcontextual model in physical education and leisure-time contexts: Examining the role of basic psychological need satisfaction. British Journal of Educational Psychology, 80(4), 647-670. http://doi.org/10.1348/000709910X487023

Barkoukis, V., Katsani, K., \& Ourda, D. (2012). Antecedents and Consequences of Self-Regulated Learning in Physical Education. Em V. Chatzi \& V. Barkoukis (Eds.), Psychology of Self-regulation (pp. 129-146). New York: Nova Science Publishers.

Barkoukis, V., Ntoumanis, N., \& Thøgersen-Ntoumani, C. (2010). Developmental changes in achievement motivation and affect in physical education: Growth trajectories and demographic differences. Psychology of Sport and $E_{X}$ ercise, 11(2), 83-90. http://doi.org/10.1016/j.psychsport.2009.04.0 08

Barkoukis, V., Tzorbatzoudis, H., Grouios, G., \& Gabriilides, A. (2003). Psychometric characteristic of Intrinsic Motivation Inventory (IMI) on a sample of junior-high school students. Physical Education \& Sport, 48, 73-81.

Belton, T., \& Priyadharshini, E. (2007). Boredom and schooling: a cross-disciplinary exploration. Cambridge Journal of Education, 37(4), 579595.

http://doi.org/10.1080/03057640701706227

Brown, A. L. (1987). Metacognition, executive control, self-regulation, and other more mysterious 
mechanisms. Em F. E. Weinert \& R. Kluwe (Eds.), Metacognition, motivation, and understanding (pp. 65-116). Hillsdate: L. Erlbaum Associates.

Cox, A. E., Smith, A. L., \& Williams, L. (2008). Change in physical education motivation and physical activity behavior during middle school. The Journal of Adolescent Health: Official Publication of the Society for Adolescent Medicine, 43(5),

506-513. http://doi.org/10.1016/j.jadohealth.2008.04.0 20

Cox, A. E., \& Williams, L. (2008). The roles of perceived teacher support, motivational climate, and psychological need satisfaction in students' physical education motivation. Journal of Sport \& Exercise Psychology, 30(2), 222-239.

Deci, E. L., \& Ryan, R. M. (2000). The "What» and "Why" of Goal Pursuits: Human Needs and the Self-Determination of Behavior. Psychological Inquiry, 11(4), 227-268. http://doi.org/10.1207/S15327965PLI1104_01

Deci, E. L., \& Ryan, R. M. (2002). Handbook of Selfdetermination Research. Rochester, NY: University Rochester Press.

Deci, E. L., \& Ryan, R. M. (2011). Self-determination theory. Em P. A. M. V. Lange, A. W. Kruglanski, \& E. T. Higgins (Eds.), Handbook of Theories of Social Psychology: Volume 1 (pp. 416-437). Thousand Oaks, CA: SAGE.

Duda, J. L., \& Nicholls, J. G. (1992). Dimensions of achievement motivation in schoolwork and sport. Journal of Educational Psychology, 84(3), 290-299. 0663.84.3.290

Duncan, L. R., Hall, C. R., Wilson, P. M., \& Jenny, O. (2010). Exercise motivation: a cross-sectional analysis examining its relationships with frequency, intensity, and duration of exercise. International Journal of Behavioral Nutrition and Physical Activity, 7(1), 1-9. http://doi.org/10.1186/1479-5868-7-7

Efklides, A. (2001). Metacognitive experiences in problem solving: Metacognition, motivation, and self-regulation. Em A. Efklides, J. Kuhl, \& R. M. Sorrentino (Eds.), Trends and Prospects in Motivation Research (pp. 297-323). Dordrecht, The Netherlands: Kluwer Academic Publishers.

Flavell, J. H. (1979). Metacognition and cognitive monitoring: A new area of cognitive-developmental inquiry. American Psychologist, 34(10), 906-911. http://doi.org/10.1037/0003066X.34.10.906

Goetz, T., Frenzel, A. C., Pekrun, R., \& Hall, N. C. (2006). The Domain Specificity of Academic Emotional Experiences. The Journal of Experimental Education, 75(1), 5-29. http://doi.org/10.3200/JEXE.75.1.5-29
Hagger, M. S., \& Chatzisarantis, N. (2007). The trans-contextual model of motivation. Em M. S. Hagger \& N. Chatzisarantis (Eds.), Intrinsic Motivation and Self-determination in Exercise and Sport (pp. 53-70). Champagn, IL: Human Kinetics.

Hagger, M. S., Chatzisarantis, N., \& Biddle, S. J. H. (2002). A meta-analytic review of the theories of reasoned action and planned behaviour in physical activity: Predictive validity and the contribution of additional variables. Journal of Sport and Exercise Psychology, 24(1), 3-32.

Hagger, M. S., Chatzisarantis, N., Culverhouse, T., \& Biddle, S. J. H. (2003). The processes by which perceived autonomy support in physical education promotes leisure-time physical activity intentions and behavior: a trans-contextual model. Journal of Educational Psychology, 95(4), 784-795. http://doi.org/10.1037/00220663.95.4.784

Kaplan, A. (2008). Clarifying Metacognition, SelfRegulation, and Self-Regulated Learning: What's the Purpose? Educational Psychology Review, 20(4), 477-484. http://doi.org/10.1007/s10648-008-9087-2

Kass, S. J., Wallace, J. C., \& Vodanovich, S. J. (2003). Boredom proneness and sleep disorders as predictors of adult attention deficit scores. Journal of Attention Disorders, 7(2), 83-91. http://doi.org/10.1177/108705470300700202

Kearney, C. A. (2008). School absenteeism and school refusal behavior in youth: A contemporary review. Clinical Psychology Review, 28(3), 451-471. http://doi.org/10.1016/j.cpr.2007.07.012

Klein, G., \& Hardman (Eds.). (2008). Physical education and sport education in European Union. Paris: Editions Revue EP.S.

Kolovelonis, A., Goudas, M., \& Dermitzaki, I. (2011). The effect of different goals and self-recording on self-regulation of learning a motor skill in a physical education setting. Learning and Instruction, 21(3), 355-364. http://doi.org/10.1016/j.learninstruc.2010.04.001

Martini, R., \& Shore, B. M. (2008). Pointing to parallels in ability-related differences in the use of metacognition in academic and psychomotor tasks. Learning and Individual Differences, 18(2), 237-247. http://doi.org/10.1016/j.lindif.2007.08.004

McAuley, E., Duncan, T., \& Tammen, V. V. (1989). Psychometric properties of the Intrinsic Motivation Inventory in a competitive sport setting: a confirmatory factor analysis. Research Quarterly for Exercise and Sport, 60(1), 48-58. http://doi.org/10.1080/02701367.1989.10607 413

Nett, U. E., Goetz, T., \& Daniels, L. M. (2010). What to do when feeling bored?: Students' strategies 
148 | Y Karagiannidis, V Barkoukis, V Gourgoulis, G Kosta, P Antoniou

for coping with boredom. Learning and Individual Differences, 20(6), 626-638. http://doi.org/10.1016/j.lindif.2010.09.004

Niemiec, C. P., \& Ryan, R. M. (2009). Autonomy, competence, and relatedness in the classroom: applying self-determination theory to educational practice. Theory and Research in Education, $\quad 7(2), \quad 133-144$. http://doi.org/10.1177/1477878509104318

Nietfeld, J. (2003). An Examination of Metacognitive Strategy Use and Monitoring Skills by Competitive Middle Distance Runners. Journal of Applied Sport Psychology, 15(4), 307-320. http://doi.org/10.1080/714044199

Ntoumanis, N. (2001). A self-determination approach to the understanding of motivation in physical education. British Journal of Educational Psychology, 71(2), 225-242. http://doi.org/10.1348/000709901158497

Ntoumanis, N. (2002). Motivational clusters in a sample of British physical education classes. Psychology of Sport and Exercise, 3(3), 177$194 . \quad$ http://doi.org/10.1016/S14690292(01)00020-6

Ntoumanis, N. (2005). A prospective study of participation in optional school physical education using a self-determination theory framework. Journal of Educational Psychology, 97(3), 444453. http://doi.org/10.1037/00220663.97.3.444

Ntoumanis, N., Barkoukis, V., \& Thøgersen-Ntoumani, C. (2009). Developmental trajectories of motivation in physical education: Course, demographic differences, and antecedents. Journal of Educational Psychology, 101(3), 717-728. http://doi.org/10.1037/a0014696

Office for the Minister of Children and Youth Affairs. (2007). Teenspace: A national recreation policy for young people. Dublin: Minister for Children and Youth Affairs.

Ommundsen, Y. (2003). Implicit Theories of Ability and Self-regulation Strategies in Physical Education Classes. Educational Psychology, 23(2), 141-157.

http://doi.org/10.1080/01443410303224

Ommundsen, Y. (2006). Pupils' self-regulation in physical education: the role of motivational climates and differential achievement goals. European Physical Education Review, 12(3), 289315.

http://doi.org/10.1177/1356336X06069275

Pekrun, R., Goetz, T., Daniels, L. M., Stupnisky, R. H., \& Perry, R. P. (2010). Boredom in achievement settings: Exploring control-value antecedents and performance outcomes of a neglected emotion. Journal of Educational Psychology, 102(3), 531-549. http://doi.org/10.1037/a0019243

Pekrun, R., Goetz, T., Titz, W., \& Perry, R. P. (2002). Academic emotions in students' self-regulated learning and achievement: A program of qualitative and quantitative research. Educational Psychologist, 37(2), 91-105. http://doi.org/10.1207/S15326985EP3702_4

Preacher, K. J., \& Hayes, A. F. (2008). Asymptotic and resampling strategies for assessing and comparing indirect effects in multiple mediator models. Behavior Research Methods, 40(3), 879-891.

http://doi.org/10.3758/BRM.40.3.879

Prochaska, J. J., Sallis, J. F., Slymen, D. J., \& McKenzie, T. L. (2003). A longitudinal study of children's enjoyment of physical education. Pediatric Exercise Science, 15(2), 170-178.

Reeve, J., \& Jang, H. (2006). What teachers say and do to support students' autonomy during a learning activity. Journal of Educational Psychology, 98(1), 209-219. http://doi.org/10.1037/0022-0663.98.1.209

Reeve, J., Jang, H., Carrell, D., Jeon, S., \& Barch, J. (2004). Enhancing Students' Engagement by Increasing Teachers' Autonomy Support. Motivation and Emotion, 28(2), 147-169. http://doi.org/10.1023/B:MOEM.0000032312. 95499.6f

Ryan, R. M., \& Connell, J. P. (1989). Perceived locus of causality and internalization: Examining reasons for acting in two domains. Journal of Personality and Social Psychology, 57(5), 749-761. http://doi.org/10.1037/0022-3514.57.5.749

Ryan, R. M., \& Deci, E. L. (2000a). Intrinsic and extrinsic motivations: Classic definitions and new directions. Contemporary Educational Psychology, 25(1), 54-67. http://doi.org/10.1006/ceps.1999.1020

Ryan, R. M., \& Deci, E. L. (2000b). Self-determination theory and the facilitation of intrinsic motivation, social development, and well-being. American Psychologist, 55(1), 68-78. http://doi.org/10.1037/0003-066X.55.1.68

Ryan, R. M., \& Deci, E. L. (2006). Self-regulation and the problem of human autonomy: does psychology need choice, self-determination, and will? Journal of Personality, 74(6), 1557-1585. http://doi.org/10.1111/j.14676494.2006.00420.x

Ryan, R. M., Williams, G. C., Patrick, H., \& Deci, E. L. (2009). Self-determination theory and Physical Activity: the dynamics of motivation in development and wellness. Hellenic Journal of Psychology, 6(2), 107-124.

Sallis, J. F., Prochaska, J. J., \& Taylor, W. C. (2000). A review of correlates of physical activity of children and adolescents. Medicine and Science in Sports and Exercise, 32(5), 963-975.

Scanlan, T. K., \& Simmons, J. P. (1992). The construct of sport enjoyment. Em G. C. Roberts (Ed.), Motivation in sport and exercise (pp. 199-216). Champagn, IL: Human Kinetics. 
Smith, M. A., \& Saint-Pierre, P. E. (2009). Secondary Students' Perceptions of Enjoyment in Physical Education: An American and English Perspective. The Physical Educator, 66(4), 209-221.

Solmon, M. A., \& Boone, J. (1993). The impact of student goal orientation in physical education classes. Research Quarterly for Exercise and Sport, 64(4),

418-424. http://doi.org/10.1080/02701367.1993.10607 595

Solmon, M. A., \& Lee, A. M. (1997). Development of an instrument to assess cognitive processes in physical education classes. Research Quarterly for Exercise and Sport, 68(2), 152-160. http://doi.org/10.1080/02701367.1997.10607 991

Standage, M., Duda, J. L., \& Ntoumanis, N. (2003). A model of contextual motivation in physical education: Using constructs from self-determination and achievement goal theories to predict physical activity intentions. Journal of Educational Psychology, 95(1), 97-110. http://doi.org/10.1037/0022-0663.95.1.97

Standage, M., Duda, J. L., \& Ntoumanis, N. (2005). A test of self-determination theory in school physical education. The British Journal of Educational Psychology, 75(3), 411-433. http://doi.org/10.1348/000709904X22359

Standage, M., Duda, J. L., \& Ntoumanis, N. (2006). Students' motivational processes and their relationship to teacher ratings in school physical education: a self-determination theory approach. Research Quarterly for Exercise and Sport, $77(1)$,

100-110. http://doi.org/10.1080/02701367.2006.10599 336

Taylor, I. M., Ntoumanis, N., Standage, M., \& Spray, C. M. (2010). Motivational predictors of physical education students' effort, exercise intentions, and leisure-time physical activity: a multilevel linear growth analysis. Journal of Sport \& Exercise Psychology, 32(1), 99-120.

Theodosiou, A. (2004). Metacognitive strategies and motivation climate in physical education (Doctoral Dissertation). Democritus University of Thrace, Komotini, Greece.

Theodosiou, A., Mantis, K., \& Papaioannou, A. (2008). Student self-reports of metacognitive activity in physical education classes. Age-group differences and the effect of goal orientations and perceived motivational climate. Educational Research and Reviews, 3(12), 353-364.

Theodosiou, A., \& Papaioannou, A. (2006). Motivational climate, achievement goals and metacognitive activity in physical education and exercise involvement in out-of-school settings. Psychology of Sport and Exercise, 7(4), 361-379. http://doi.org/10.1016/j.psychsport.2005.10.0 02
Thomas, G. P., \& Mee, D. A. K. (2005). Changing the Learning Environment to Enhance Students' Metacognition in Hong Kong Primary School Classrooms. Learning Environments Research, 8(3), 221-243. http://doi.org/10.1007/s10984005-1565-6

Vallerand, R. J. (1997). Toward a hierarchical model of intrinsic and extrinsic motivation. Em M. P. Zanna (Ed.), Advances in Experimental Social Psychology (Vol. 29, pp. 271-360). New York: Academic Press.

Vallerand, R. J. (2001). A hierarchical model of intrinsic and extrinsic motivation in sport and exercise. Em G. C. Roberts (Ed.), Advances in Motivation in Sport \& Exercise (pp. 263-319). Champagn, IL: Human Kinetics.

Vallerand, R. J. (2007). A hierarchical model of intrinsic and extrinsic motivation for sport and physical activity. Em Intrinsic Motivation and Self-determination in Exercise and Sport (pp. 255-279). Champaign, IL: Human Kinetics.

Vansteenkiste, M., Simons, J., Soenens, B., \& Lens, W. (2004). How to become a persevering exerciser? Providing a clear, future intrinsic goal in an autonomy-supportive way. Journal of Sport \& Exercise Psychology, 26(2), 232-249.

Van Tilburg, W. A. P., \& Igou, E. R. (2011). On boredom and social identity: a pragmatic meaningregulation approach. Personality \& Social Psychology Bulletin, 37(12), 1679-1691. http://doi.org/10.1177/0146167211418530

Van Tilburg, W. A. P., Igou, E. R., \& Sedikides, C. (2013). In search of meaningfulness: nostalgia as an antidote to boredom. Emotion, 13(3), 450-461. http://doi.org/10.1037/a0030442

Veenman, M. V. J., Wilhelm, P., \& Beishuizen, J. J. (2004). The relation between intellectual and metacognitive skills from a developmental perspective. Learning and Instruction, 14(1), 89$109 . \quad$ http://doi.org/10.1016/j.learninstruc.2003.10.004

Wallhead, T. L., \& Buckworth, J. (2004). The role of physical education in the promotion of youth physical activity. Quest, 56(3), 285-301. http://doi.org/10.1080/00336297.2004.10491 827

Wasson, A. S. (1981). Susceptibility to boredom and deviant behavior at school. Psychological Reports, $\quad 48(3)$, 901-902. http://doi.org/10.2466/pr0.1981.48.3.901

Webb, T. L., \& Sheeran, P. (2006). Does changing behavioral intentions engender behavior change? A meta-analysis of the experimental evidence. Psychological Bulletin, 132(2), 249$268 . \quad$ http://doi.org/10.1037/00332909.132.2.249

Wegner, L., Flisher, A. J., Chikobvu, P., Lombard, C., \& King, G. (2008). Leisure boredom and high school dropout in Cape Town, South Africa. Journal of Adolescence, 31(3), 421-431. 
150 | Y Karagiannidis, V Barkoukis, V Gourgoulis, G Kosta, P Antoniou

http://doi.org/10.1016/j.adoles-

cence.2007.09.004

Weiss, M., Kimmel, L., \& Smith, A. (2001). Determinants of sport commitment among junior tennis players: enjoyment as a mediating variable. $P e-$ diatric Exercise Science, 13(2), 131-144.

Wilson, P. M., \& Rodgers, W. M. (2004). The relationship between perceived autonomy support, exercise regulations and behavioral intentions in women. Psychology of Sport and Exercise, 5(3), 229-242. http://doi.org/10.1016/S14690292(03)00003-7

Wininger, S. R., \& DeSena, T. M. (2012). Comparison of Future Time Perspective and Self-Determination Theory for Explaining Exercise Behavior. Journal of Applied Biobehavioral Research, $17(2)$, 109-128. http://doi.org/10.1111/j.17519861.2012.00081.x
Winne, P. H., \& Nesbit, J. C. (2010). The psychology of academic achievement. Annual Review of Psychology, 61,
http://doi.org/10.1146/annurev.psych.093008.100348

Yli-Piipari, S., Wang, C. K. J., Jaakkola, T., \& Liukkonen, J. (2012). Examining the Growth Trajectories of Physical Education Students' Motivation, Enjoyment, and Physical Activity: A Person-Oriented Approach. Journal of Applied Sport Psychology, 24(4), 401-417. http://doi.org/10.1080/10413200.2012.67709 6

Yli-Piipari, S., Watt, A., Jaakkola, T., Liukkonen, J., \& Nurmi, J.-E. (2009). Relationships between physical education students' motivational profiles, enjoyment, state anxiety, and self-reported physical activity. Journal of Sports Science \& Medicine, 8(3), 327-336. 